Hung, J. \& Yang, D. (2015). The Validation of an Instrument for Evaluating the Effectiveness of Professional Development Program on Teaching Online. Journal of Educational Technology Development and Exchange,

$8(1), 17-37$.

\title{
The Validation of an Instrument for Evaluating the Effectiveness of Professional Development Program on Teaching Online
}

\author{
Jui-Long Hung \\ Boise State University \\ Dazhi Yang \\ Boise State University
}

\begin{abstract}
Attending professional development (PD) on teaching online is becoming popular for teachers in today's K-12 online education. Due to the unique characteristics of the online instructional environments, surveys become the most feasible approach to evaluate the effectiveness of PD programs. However, there is no validated, open-access instrument available to satisfy the needs. Purpose of this study is to conduct construct validity, content validity, concurrent validity, and reliability tests on an open-access instrument for K-12 PD for online teaching. With the exception of a few items that have minor issues on content and construct validity, results show that the survey is, in general, a valid and reliable instrument. Suggestions and potential applications of the instrument are also discussed.
\end{abstract}

Keywords: K-12 Online Professional Development, Construct Validity, Content Validity, Concurrent Validity, Reliability

\section{Background}

The effectiveness of online courses depends mostly upon the instructor's effectiveness of teaching online (Rice, 2012). However, knowledge and skills developed to teach in face-to-face settings are not adequate for teaching online courses (Deubel, 2008). Many of today's online instructors still lack necessary skills and knowledge to teach effectively in online settings. Few teacher education programs in the United States offer training in learning theories or teaching pedagogies specifically for online environments (Patrick \& Dawley, 2009). According to a recent report on the status of professional development and needs of $\mathrm{K}-12$ online teachers (Dawley, Rice, \& Hinck, 2010), approximately $12 \%$ of new teachers have had never taught faceto-face and $25 \%$ received no training in online teaching pedagogies prior to teaching online. Professional development (PD) programs, including workshops and courses designed for effective online teaching, are the most common way for teachers to obtain the necessary knowledge, skills, and competency for online teaching. 
Assessment and evaluation of such PD programs and instructors' competency and performance after receiving PD training are conducted through various means, such as interviews, observations, and surveys. As more and more PD programs are conducted online, survey is often the most practical and adopted approach to evaluate the effectiveness of PD programs.

Currently, teachers' PD in online teaching encounters two major problems. First, the effectiveness of PD should be ideally measured by teachers' long-term performance improvement after their PD training (Loucks-Horsley, Stiles, \& Hewson, 1996; Knight, Carrese, \& Wright, 2007). However, tracking and assessing teachers' long-term performance improvement, especially when the PD is conducted online and participants are from various school districts and states, is difficult. This is why most online PD programs rely on post PD surveys to measure the effectiveness of PD training. Some post PD surveys only measure participants' satisfaction. However, high satisfaction is not equal to performance improvement after the PD training. Second, although teachers' self-efficacy positively correlates with their practice (Long \& Moore, 2008; Woolfolk Hoy, Davis, \& Pape, 2006) and student achievement (Martin \& Marsh, 2006; Siegle \& McCoach, 2007), there is no validated and reliable instrument for measuring teachers' self-efficacy in terms of teaching online. Furthermore, the instrument should be open access so it can be tested for validity and reliability with various populations and methods.

The purpose of this study is to conduct validity and reliability tests on an openaccess instrument for $\mathrm{K}-12$ teachers' $\mathrm{PD}$ on online teaching, primarily using the Rasch Model analyses. The major research question was whether the Online Educator
Self-Efficacy Scale (OESES) had been a valid and reliable instrument for assessing and/or evaluating the effectiveness of online PD programs, including workshops and courses.

\section{Literature Review}

\subsection{Teacher Efficacy and Professional Development}

Bandura (1997) defined self-efficacy as "beliefs in one's capabilities to organize and execute the courses of action required to produce given attainments" (p.2). Although teacher efficacy is a self-perception, not an objective measure of teaching effectiveness, it represents teachers' expectation that their efforts will bring about student learning. Multiple studies found that teachers with high efficacy beliefs generate stronger student achievement than teachers with lower teacher efficacy (Goddard, Hoy, \& Hoy, 2004; Ross \& Bruce, 2007; Tschannen-Moran, Hoy, \& Hoy, 1998). Self-efficacy can further be classified into two types: general and personal teaching self-efficacy. General teaching self-efficacy refers to "briefs that teachers are able to bring about student learning despite out-ofschool constraints" (Bandura, 1997, p.80). Personal teaching self- efficacy refers to "briefs in one's capabilities to organize and execute the courses of action required to produce given attainments" (Bandura, 1997, p.2). The effects of teacher efficacy on student achievement can be summarized into the following factors:

- Teachers with higher efficacy adopt challenging goals, try harder to achieve them, persist through obstacles, and develop strategies for managing their emotional states. (Bandura, 1993; 1997). 
- Teachers with high efficacy are more likely to try out new teaching ideas, particularly techniques that are difficult to implement and involve risks, such as sharing computer or device control with students. (Haney, Czerniak, \& Lumpe, 1996; Ross, 1998).

- Teachers with high efficacy use effective classroom management strategies to stimulate student autonomy by reducing custodial control and keeping students on tasks (Woolfolk, Rosoff, \& Hoy, 1990).

- Teachers with high-efficacy can expend their efforts with low ability or achieving students. High-efficacy teachers have positive attitudes toward low achieving students, build friendly relationships with them, and set higher academic standards for this group than do low-efficacy teachers (Ross \& Bruce, 2007).

- Teacher efficacy leads to strengthen selfperceptions of students' academic abilities. As student efficacy becomes stronger, students become more enthusiastic about schoolwork and more willing to interact with the teacher. Then the positive cycle reflects directly on achievement (Ashton, Webb, \& Doda, 1983; Ashton \& Webb, 1986).

Overall, studies have shown that teachers' self-efficacy has high positive correlations with teaching practice (Goddard, 2002; Goddard \& Goddard, 2001; Knoblauch \& Hoy, 2008; Long \& Moore, 2008; Margolis \& McCabe, 2006; Milner, 2002; Woolfolk Hoy \& Davis, 2006) and student achievement (Martin \& Marsh, 2006; Siegle \& McCoach, 2007). As a result, teacher's self-efficacy has been adopted as an important indicator to evaluate the effectiveness of PD trainings (Faseyitan, Libii, \& Hirschbuhl, 1996;
Milbrath \& Kinzie, 2000; Overbaugh \& Lu, 2008; Ross \& Bruce, 2007; Shechtman, Levy, \& Leichtentritt, 2005).

\subsection{Validity}

An assessment instrument should be valid and reliable in terms of the inferences and scores it produces. Validity refers to the degree to which the evidence supports that the interpretations are correct and the manner in which interpretations are used as appropriate (AERA, APA \& NCME, 1999). Traditionally, there are three major validity types related to assessment or instrument validation: construct, content, and criterionrelated validities (Crocker \& Algina, 1986).

2.2.1. Construct Validity. Construct validity refers to the degree to which an instrument or an assessment assesses the theoretical construct it intends to measure. Responses from instrument participants can be interpreted as reflecting the theoretical construct. The Rasch model (Bond \& Fox, 2013), a model based on Item Responses Theory, is one of the most popular approaches for testing construct validity (Comer, Conaghan, \& Tennant, 2011; Runnels, 2012). The Rasch model contains two determinants of an item response: the respondent's trait level and the item's difficulty level. A teacher with high level of self-efficacy in facilitating online discussion will be more likely to endorse or agree with an item that measures skills of discussion facilitation than a low self-efficacy teacher in the same skill. A question with higher difficult level will be less likely to be endorsed or agreed to by respondents than one with lower difficult level. The Rasch model estimates responses based on item difficulty level and respondent trait level. When the actual responses are closed to the estimated responses, the instrument has high construct validity (fitting with the model). 
2.2.2. Content Validity. Content validity is the degree to which a test or an instrument measures what it is supposed to measure with sufficient coverage (Brown, 1996). Therefore, there are two threats that influence content validity. First, the instrument contains construct-irrelevant items (Furr \& Bacharach, 2007), including bad writing questions that can cause misunderstanding. Second, the instrument fails to include the full range of contents that is relevant to the construct (Furr \& Bacharach, 2007). In practice, content validity is usually evaluated by subject experts within the construct field. Lynn (1986) and Rubio, Berg-Weger, Tebb, Lee, and Rauch (2003) proposed a systematic procedure to conduct content validity test, including number of experts in the panel, survey design and development, survey investigation, and data analysis. The detailed procedures are discussed later.

2.2.3. Criterion Validity. Criterion validity refers to the results of an assessment correlate with a current or future event. (Furr \& Bacharach, 2007). Therefore, criterion validity can be further divided into concurrent validity and predictive validity. Concurrent validity refers to the degree to which the results obtained by the target survey instrument correlate with the results obtained for the same population by another "validated" instrument at the same time. Predictive validity refers to the degree to which measurement scores are correlated with relevant variables that are measured at a future point in time. Because it is difficult to recruit and evaluate the same group of participants at a future point, concurrent validity is more common than predictive validity in the criterion validity test.

Among above validity types, construct validity is more important and broader than the other two validity tests from a more contemporary perspective of assessment and evaluation (Furr \& Bacharach, 2007;
Messick, 1995). In other words, content and criterion validities should be considered within the context of construct validity. In this study, the target instrument is validated by construct validity, content validity, and concurrent validity.

\subsection{Reliability}

Reliability refers to the consistency of the assessment outcomes generated at different times. The most popular approach for testing instrument's reliability is internal consistency reliability (Hogan, Benjamin, \& Brezinski, 2000) and most common internal consistency measure is Cronbach's alpha test (Cronbach, 1951). The Rasch model provides two reliability measures: Rasch item reliability and Rasch person reliability (Bond \& Fox, 2013). A reliable instrument should obtain similar outcomes if the instrument is conducted toward another group of participants with the same traits known as Rasch item reliability (Bond \& Fox, 2007). A reliable respondent should give the same or similar responses toward another instrument with the same construct and difficulty level of questions known as Rasch person reliability (Wright \& Masters, 1982). This study adopts the following three reliability tests: Cronbach's alpha, Rasch item reliability, and Rasch person reliability.

\subsection{Rasch Model}

Item responses theory (IRT) is a psychometric approach that emphasizes the fact of responses to any instrument item that is influenced by abilities of the individual respondents and items (Furr \& Bacharach, 2007). As one of the most popular model based on IRT, the Rasch model is a oneparameter item response theoretic model (Bond \& Fox, 2013) and widely applied 
in the development and analyses of largescale achievement assessment. In addition to assessment instrument validation, it is increasingly used in the validity and reliability tests of survey instruments (Bond \& Fox, 2013).

The core of the Rasch model is based on a mathematical formula that states the relationships between respondents and the measurement items that operationalize one trait. The Rasch model estimates difficulty or agreeability of individual items (item logits) and ability or attitude of individuals (person logits), where a logit is a translation of the raw responses. In other words, raw responses are nonlinearly transformed into position estimates for items and persons. The model is sensitive to identify intentional or unintentional cheating, guessing, or any other variable(s) that might influence the responses provided. Fit statistics provide the fit indices of the data to the model and the usefulness of the measure. Fit statistics contain the average fit (mean square and standardized) of persons and items, and fit statistics reflecting the appropriateness of rating scale category use. The fit statistics are calculated by differencing each pair of observed and model-expected responses, squaring the differences, summing over all pairs, averaging, and standardizing to approximate a unit-normal (z) distribution. The expected values of the mean square and standardized fit indices are 1.0 and 0.0 , respectively, if the data fit the model.

Person fit in the Rasch model is an index of whether individuals are responding to items in a consistent manner. Responses may become inconsistent when respondents are bored and careless to the task, when they are confused, or when an item induces an unusually prominent response. Correspondingly, item fit is an index of whether items function logically and provide a continuum useful for all respondents. An item may become "misfit" when it is too complex or confusing, or when it actually measures a different construct.

At the item level, fit statistics are further divided into "infit" (weighted by the distance between the person position and the item difficulty) and as "outfit" (an unweighted measure). Infit is less sensitive than outfit to extreme responses. Both outfit and infit aim to identify questions with high ratio of unmodeled variance (responses cannot be explained by the model) or questions with too low variance (responses are too predictable). A well-designed survey should use the same language that respondents use and carefully frame items in that language on the survey. Fit statistics allow researchers to test whether survey questions communicate well with respondents.

Rasch model has been widely used in survey instrument validation for educational studies, such as self-efficacy (Lamb, Vallett, \& Annetta, 2014), success of instructional intervention (Royal \& Tabor, 2008), and perceptions of instructors or students (Kyriakides, Kaloyirou, \& Lindsay, 2006). For example, Lamb, Vallett, and Annetta (2014) validated an instrument called SETS-SF aimed to investigate selfefficacy related to scientific reasoning, computer technology, and video gaming on adolescent students. The authors collected survey responses from 651 students in 15 schools. In addition to construct validity and Rasch item/person reliability, the authors also examined construct representativeness (content validity) and external factor validity (validity for making a generalization). The study showed that combining multiple approaches/analysis to complete a multifaceted examination of 
evidence for the various aspects of validity is common.

\section{Instrument}

\subsection{The Online Educator Self-Efficacy Scale (OESES)}

The Online Teaching Associates (OTA) is an organization that provides PD courses for teachers with the knowledge, skills, and dispositions needed to be effective teachers online (OTA, 2012). The OTA-121 is a fully online professional development course, which was designed to help K-12 educators develop and demonstrate instructional proficiencies and dispositions supporting student performance in blended and fully online learning environments. The course design aims to align with and address applicable professional standards including: (a) iNACOL's National Standards for Quality Online Teachers (NSQOT) (iNACOL, 2011), (b) ISTE's NETSStandards for Teachers (ISTE, 2008), and (c) the Partnership for 21 st Century Skills Framework for 21 st Century Learning (Partnership for 21st Century Skills, 2011.)

The Online Educator Self-Efficacy Scale (OESES) aims to measure teacher's self-efficacy on online teaching capabilities after online PD. It is a four-point Likert scale (Strongly Agree, Agree, Disagree, and Strongly Disagree) survey with a total of 59 questions (see Appendix A). The instrument consists of the following parts: (a) 38 selfefficacy questions for investigating online teaching capabilities, (b) 10 General SelfEfficacy (GSE) questions (Schwarzer, \& Jerusalem, 1995) for testing concurrent validity and have been adopted and validated by many studies with hundreds of thousands of participants, and (c) 11 questions for investigating participants' satisfaction after the PD training.

The purpose of this study is to test validity and reliability of the 38 selfefficacy questions. These questions were developed to evaluate respondent's selfefficacy based on the iNACOL's National Standards for Online Teaching (http://www. inacol.org/cms/wp-content/uploads/2012/

09/iNACOL Teachingstandardsv2. pdf) in eleven online teaching capabilities (see below). Each of capabilities consists of three to four survey questions.

- The online teacher knows the primary concepts and structures of effective online instruction and is able to create learning experiences to enable student success.

- The online teacher understands and is able to use a range of technologies, both existing and emerging, that effectively support student learning and engagement in the online environment.

- The online teacher plans, designs, and incorporates strategies to encourage active learning, application, interaction, participation, and collaboration in the online environment.

- The online teacher promotes student success through clear expectations, prompt responses, and regular feedback.

- The online teacher models, guides, and encourages legal, ethical, and safe behavior related to technology use.

- The online teacher is cognizant of the diversity of student academic needs and incorporates accommodations into the online environment.

- The online teacher demonstrates competencies in creating and 
implementing assessments in online learning environments in ways that ensure validity and reliability of the instruments and procedures.

- The online teacher develops and delivers assessments, projects, and assignments that meet standards-based learning goals and assesses learning progress by measuring student achievement of the learning goals.

- The online teacher demonstrates competency in using data from assessments and other data sources to modify content and to guide student learning.

- The online teacher interacts in a professional, effective manner with colleagues, parents, and other members of the community to support students' success.

- The online teacher arranges media and content to help students and teachers transfer knowledge most effectively in the online environment.

\section{Method}

\subsection{Data Collection}

All data were collected from the participants in an OTA-121 course in 2010 and 2011 cohorts of an American Recovery and Reinvestment Act (ARRA) project, which was funded through the Wisconsin Department of Public Instruction, in collaboration with OTA. The participants were recruited from potential online teachers with the expectation that these initial participants would become a core group of online professional development trainers for their region and/or school districts after completing the PD training.
Survey Monkey, an online survey tool, was used to collect participants' responses. In total, 231 teachers participated in the online PD training and completed the OESES survey.

\subsection{Analytic Tools}

Rasch Model analysis (Alagumalai, Curtis, \& Hungi, 2005) was applied for construct validity and reliability tests. An expert panel review was conducted for the content validity (Lynn, 1986; Rubio, et al., 2003). Spearman's correlation was used to test concurrent validity. All statistical tests were conducted by using SPSS 21 and Winsteps 3.74.

\section{Results}

Data collected from a total of 231 respondents were used for the analysis. All reliability and validity tests focused on 38 self-efficacy questions only. The 10 GSE questions were used to test concurrent validity.

\subsection{Reliability Tests}

Three reliability tests, Cronbach's Alpha, Rasch person reliability, and Rasch item reliability, were applied to test the reliability of the 38 OESES self-efficacy items. As shown in Table 1, the 38 OESES survey items have high internal reliability (Cronbach's Alpha $=0.968)$. In addition, the Cronbach coefficient does not obtain significant improvement by removing any of individual items, which means it is not necessary to remove any items in order to improve the instrument's reliability. As shown in Table 2, the OESES survey yielded high reliabilities on both Rasch person reliability $(0.82)$ and Rasch item reliability $(0.94)$. These values indicate 
that the survey's scale is able to identify individual differences among respondents and that the items are sufficiently spread out along the scale. participants to every item. Fit statistics are then derived from a comparison of the expected and observed responses using standardized residuals (the difference

Table 1. Results of Internal Reliability

Cronbach's Alpha

Nof Items

.968

38

Calculating Fit statistics

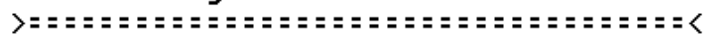

Standardized Residuals N(0,1) Mean: .02 S.D.: .95

Time for estimation: $0: 0: 0.571$

Processing Table 0

OTAData_woQuestion. $x l s x$

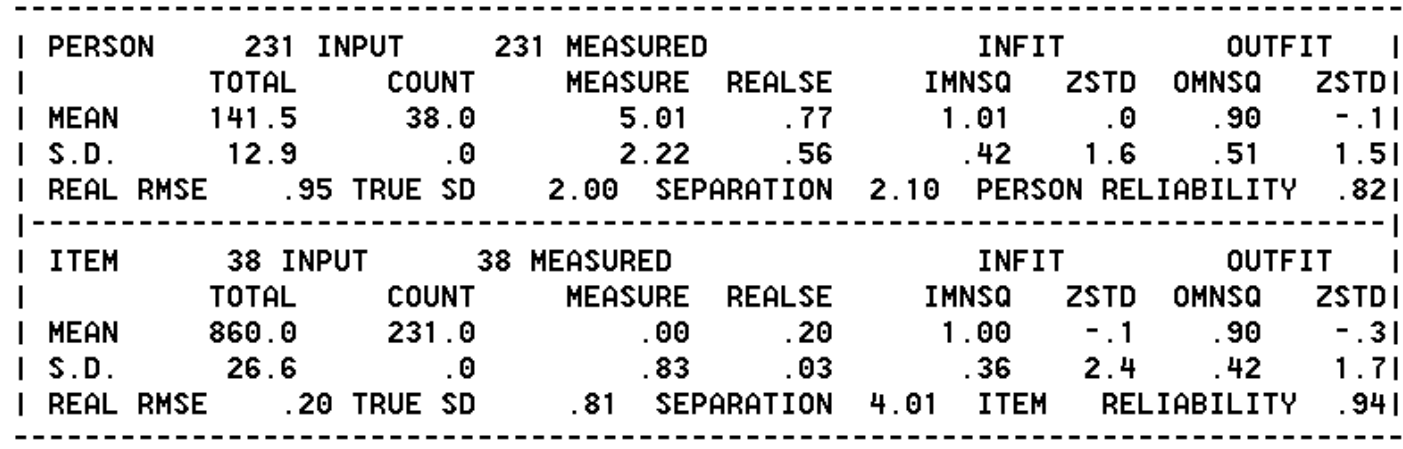

\subsection{Construct Validity}

\subsubsection{Rasch Fit Statistics Evaluation.}

The purpose of this test aims to examine how closely the data fit the model expectations. The results help address the technical-quality aspect of content evidence for construct validity as outlined by Messick (1989; 1995). Once the parameters of a Rasch model are estimated, they are used to compute expected responses of all of what is expected by the Rasch model and what is observed). The expectation values of standardized residuals' mean and standard deviation are 0 and 1 respectively. Table 2 shows results are very closed to the expectation values (mean $=0.02$ and standard deviation $=0.95)$. The results indicate, as a whole, the survey has a good fit to the Rasch Model test. 
Table 3. Results of Item Fit Analysis

\begin{tabular}{|c|c|c|c|c|c|c|c|c|c|c|c|c|}
\hline \multirow{2}{*}{$\begin{array}{l}\text { ENTRY } \\
\text { Number }\end{array}$} & \multirow{2}{*}{$\begin{array}{l}\text { TOTAL } \\
\text { SCORE }\end{array}$} & \multirow{2}{*}{$\begin{array}{l}\text { TOTAL } \\
\text { COUNT }\end{array}$} & \multirow{2}{*}{$\begin{array}{l}\text { MEA- } \\
\text { SURE }\end{array}$} & \multirow{2}{*}{$\begin{array}{l}\text { MODEL } \\
\text { S.E. }\end{array}$} & \multicolumn{2}{|c|}{ INFIT } & \multicolumn{2}{|c|}{ OUTFIT } & PT-MEASURE & \multirow{2}{*}{\multicolumn{2}{|c|}{$\begin{array}{ll}\text { EXACT } & \text { МАTCH } \\
\text { OBS } \% & \text { EXP\% }\end{array}$}} & \multirow{2}{*}{ ITEM } \\
\hline & & & & & MNSQ & ZSTD & MNSQ & ZSTD & COOR. EXP. & & & \\
\hline 3 & 866 & 231 & -.08 & .19 & 2.25 & 6.9 & 2.08 & 3.5 & A $.42 \quad 61$ & 73.1 & 81.0 & Q7* \\
\hline 2 & 863 & 231 & .02 & .18 & 1.93 & 5.6 & 1.59 & 2.2 & В .49.62 & 73.1 & 80.2 & Q6* \\
\hline 4 & 864 & 231 & -.01 & .19 & 1.37 & 2.5 & 1.85 & 2.9 & C .50.62 & 75.3 & 80.4 & Q8* \\
\hline 11 & 814 & 231 & 1.35 & .15 & 1.74 & 5.9 & 1.65 & 4.4 & D $.59 \quad .71$ & 58.1 & 68.7 & Q25* \\
\hline 1 & 875 & 231 & -.42 & .20 & 1.47 & 2.9 & 1.43 & 1.4 & Е .48 .59 & 77.4 & 83.5 & Q5* \\
\hline 19 & 883 & 231 & -.76 & .21 & .90 & -.60 & 1.33 & 1.0 & F .56 .56 & 86.6 & 85.6 & Q33 \\
\hline 27 & 829 & 231 & .99 & .16 & 1.16 & 1.5 & 1.32 & 2.1 & G .62 .68 & 72.0 & 71.5 & Q41 \\
\hline 17 & 872 & 231 & -.30 & .20 & 1.22 & 1.5 & 1.13 & .5 & Н .56 .60 & 82.3 & 82.7 & Q31 \\
\hline 6 & 795 & 231 & 1.76 & .14 & 1.16 & 1.6 & 1.21 & 1.8 & I $.66 \quad .73$ & 59.7 & 66.1 & Q13 \\
\hline 7 & 796 & 231 & 1.74 & .14 & 1.05 & .5 & 1.18 & 1.6 & $\begin{array}{lll}\mathrm{J} & .67 \quad .73\end{array}$ & 58.6 & 66.1 & Q14 \\
\hline 22 & 791 & 231 & 1.84 & .14 & 1.10 & 1.0 & 1.15 & 1.4 & K .68 .73 & 60.2 & 65.5 & Q36 \\
\hline 30 & 872 & 231 & -.30 & .20 & 1.13 & .9 & .94 & -.1 & L .60 .60 & 87.1 & 82.7 & Q44 \\
\hline 9 & 860 & 231 & .12 & .18 & 1.11 & .9 & .93 & -.2 & M .62.63 & 78.5 & 79.4 & Q23 \\
\hline 34 & 871 & 231 & -.27 & .19 & .82 & $-1,3$ & 1.09 & .4 & N .63 .60 & 84.9 & 82.4 & Q48 \\
\hline 21 & 840 & 231 & .71 & .16 & 1.01 & .2 & .88 & -.7 & $\begin{array}{llll}O & .67 & .67\end{array}$ & 73.7 & 74.0 & Q35 \\
\hline 37 & 852 & 231 & .37 & .17 & 1.00 & .1 & .76 & -1.3 & P .67 .64 & 78.0 & 77.1 & Q51 \\
\hline 14 & 882 & 231 & -.72 & .21 & .97 & -.1 & .72 & -.8 & Q $\quad .59 \quad .57$ & 91.9 & 85.3 & Q28 \\
\hline 20 & 832 & 231 & .92 & .16 & .96 & -.3 & .85 & -1.0 & R .68 .68 & 71.5 & 72.3 & Q34 \\
\hline 36 & 853 & 231 & .34 & .17 & .96 & -.3 & .78 & -1.1 & $\begin{array}{lll}\text { S } & .66 & .64\end{array}$ & 74.7 & 77.4 & Q50 \\
\hline 13 & 898 & 231 & -1.57 & .25 & .95 & -.2 & .71 & -.4 & $\begin{array}{lll}\text { s } & .50 \quad .49\end{array}$ & 90.9 & 88.8 & Q27 \\
\hline 31 & 861 & 231 & .09 & .18 & .78 & -1.8 & .95 & -.2 & r $.66 \quad .63$ & 82.8 & 79.6 & Q45 \\
\hline 10 & 844 & 231 & .60 & .17 & .88 & -1.0 & .94 & -.3 & q $.68 \quad .66$ & 75.3 & 74.9 & Q24 \\
\hline 32 & 868 & 231 & -.15 & .19 & .92 & -.5 & .73 & -1.1 & p .64 .61 & 83.3 & 81.6 & Q46 \\
\hline 16 & 872 & 231 & -.30 & .20 & .89 & -.8 & .84 & -.5 & o $.63 \quad .60$ & 83.9 & 82.7 & Q30 \\
\hline 12 & 871 & 231 & -.27 & .19 & .87 & -.9 & .70 & -1.2 & n .63 .60 & 86.0 & 82.4 & Q26 \\
\hline 15 & 864 & 231 & -.01 & .19 & .86 & -1.0 & .60 & -1.9 & m .67 .62 & 87.1 & 75.3 & Q29 \\
\hline 35 & 854 & 231 &, 31 & .17 & .86 & -1.1 & .71 & -1.5 & $1.68 \quad .64$ & 78.5 & 77.7 & Q49 \\
\hline 23 & 845 & 231 & .57 & .17 & .81 & -1.7 & .73 & -1.6 & k .70 .66 & 81.7 & 75.3 & Q37 \\
\hline 18 & 881 & 231 & -.67 & .21 & .75 & -1.7 & .56 & -1.5 & $\begin{array}{lll}\mathrm{j} & .63 & .57\end{array}$ & 89.2 & 85.1 & Q32 \\
\hline 38 & 848 & 231 & .49 & .17 & .75 & -2.3 & .62 & -2.3 & i $.72 \quad .65$ & 79.0 & 76.0 & Q52 \\
\hline 28 & 883 & 231 & -.76 & .21 & .72 & -1.9 & .47 & -1.8 & h .64 .56 & 89.8 & 85.6 & Q42 \\
\hline 29 & 884 & 231 & -.81 & .22 & .68 & -2.2 & .43 & -2.0 & g $\quad .64 \quad .56$ & 90.3 & 85.8 & Q43 \\
\hline 24 & 865 & 231 & -.05 & .19 & .67 & -2.7 & .57 & -2.0 & f .69 .62 & 84.9 & 80.7 & Q38 \\
\hline 26 & 883 & 231 & -.76 & .21 & .67 & -2.4 & .40 & -2.1 & e $.65 \quad .56$ & 88.7 & 85.6 & Q40 \\
\hline 8 & 900 & 231 & -1.70 & .26 & .66 & -2.1 & .27 & -1.7 & d $.56 \quad .47$ & 93.0 & 89.3 & Q15 \\
\hline 5 & 891 & 231 & -1.16 & .23 & .62 & -2.7 & .45 & -1.5 & c .62 .53 & 91.9 & 87.2 & Q12 \\
\hline 33 & 877 & 231 & -.50 & .20 & .60 & -3.1 & .39 & -2.5 & b $.68 \quad .58$ & 89.8 & 84.0 & Q47 \\
\hline 25 & 880 & 231 & -.63 & .21 & .59 & -3.1 & .37 & -2.5 & a $.68 \quad .57$ & 90.9 & 84.8 & Q39 \\
\hline MEAN & 860.0 & 231.0 & .00 & .19 & 1.00 & -.1 & .90 & -.3 & & 80.4 & 79.7 & \\
\hline S.D. & 26.6 & .0 & .83 & .03 & .36 & 2.4 & .42 & 1.7 & & 9.6 & 6.2 & \\
\hline
\end{tabular}




\subsubsection{Item Fit Analysis.}

Table 3 shows results of item fit analysis. Infit MNSQ is an informationweighted mean-square statistic, which is more sensitive to unexpected behavior affecting responses to items near the respondent's measure level. Outfit MNSQ is an outlier-sensitive mean-square fit statistic, more sensitive to unexpected behavior by respondents on items far from the respondent's measure level.

The value of the mean-square statistics shows the size of the randomness (i.e., the amount of distortion of the measurement system). These statistics have an expected value of 1 . Values less than 1 indicate observations that are overly predictable, possibly due to redundancy or some type of response set. Values greater than 1.0 indicate excessive unexpected variability, possibly due to a violation of unidimensionality. The criterion value for goodness-of-fit for these analyses is between 0.6 and 1.4. Items that fall outside of this range for the Infit MNSQ are marked with asterisk in Table 4. Results show
MNSQ of questions 5, 6, 7, 8, and 25 are larger than 1.4 that indicates a violation of unidimensionality. The results of Outfit are similar to results of Infit tests.

\subsubsection{Principle Components Analysis (Construct Validity).}

As shown below (Table 4), the underlying measurement system accounts for the majority of the variance in the observations $(70.8 \%)$ that indicates a strong unidimensional scale. The unexplained variance, which is considered random noise in the Rasch measurement system, is $3.3 \%$. These results indicate that overall, the OESES is a strong, unidimensional scale despite the low variance in teachers' responses.

\subsection{Content Validity}

Three content experts were invited to participate in the content validity test. These experts were higher education faculty members in the field of educational technology and each of them had at least four years of experience in training K-12 online

Table 4. Standardized Residual Variance (in Eigenvalue units)

\begin{tabular}{|c|c|c|}
\hline & Empirical & Modeled \\
\hline Total raw variance in observations $=70.8$ & & $100 \%$ \\
\hline Raw variance explained by measures $=32.8$ & $46.3 \%$ & $47.9 \%$ \\
\hline Raw variance explained by persons $=21.9$ & $30.9 \%$ & $32.0 \%$ \\
\hline Raw Variance explained by items $=10.9$ & $15.3 \%$ & $15.9 \%$ \\
\hline Raw unexplained variance (total) $=38.0$ & $53.7 \%$ & $52.1 \%$ \\
\hline Unexplained variance in 1 st contrast $=3.3$ & $4.7 \%$ & $8.8 \%$ \\
\hline
\end{tabular}


teachers and teaching fully online courses. A survey was developed for the content validity test. The procedures of the expert review followed the steps suggested by Lynn (1986) and Rubio, et al., (2003). Specifically four criteria were used to evaluate the OESES: (1) representativeness of the content domain, (2) clarity of the item, (3) factor structure, and (4) comprehensiveness (Rubio, et al., 2003). Each item was rated on a scale from 1 to 4 for representativeness and clarity. First, experts were asked to evaluate individual items' ability to represent the content domain as described in the theoretical definition (representativeness). Second, experts were asked to evaluate how clearly an item was worded (clarity). Factor structure was used to measure whether all factors related to the construct have been covered by instrument. Finally, the experts were asked to address the comprehensiveness of the measure as a whole, based on results of representativeness, clarity, and factor structure. The experts then made suggestions on specific items (comprehensiveness).

The content validity index (CVI) served as the indicator of item's representativeness and clarity based on experts' ratings. The calculation was equal to the number of experts who rated an item as three or four dividing the total number of experts (Rubio, et al., 2003). Davis (1992) suggested a CVI value of 0.8 as the threshold. Based on the results, six questions have CVI values lower than 0.8 on representativeness (listed in Table 6) and all questions have CVI values higher than 0.8 on clarity.

Table 4 shows the instrument can explain up to $70.8 \%$ of total variances. The results indicated the survey contained most factors related to the construct. Therefore, additional factor structure tests were skipped here (Rubio, et al., 2003). Suggestions based on content validity results are discussed in the discussion section.

Table 6. Questions with CVI values lower than 0.8

\begin{tabular}{llc}
\hline Question ID & \multicolumn{1}{c}{ Question Description } & CVI \\
\hline Q13 & $\begin{array}{l}\text { After completing OTA's course for teachers, I feel } \\
\text { comfortable discussing the history of contemporary } \\
\text { online education. }\end{array}$ & $100 \%$ \\
& $\begin{array}{l}\text { After completing OTA's course for teachers, I am able } \\
\text { to knowledgeably discuss national and state online } \\
\text { teaching standards and the credentialing of online } \\
\text { teachers. }\end{array}$ & $47.9 \%$ \\
& $\begin{array}{l}\text { After completing OTA's course for teachers, I can } \\
\text { describe and discuss common factors contributing to } \\
\text { heavy demands on teachers' time (24/7) from fully } \\
\text { online and blended teaching assignments. }\end{array}$ & $32.0 \%$ \\
After completing OTA's course for teachers, I am \\
confident I can successfully manage workload demands \\
from an online or blended teaching assignment. \\
After completing OTA's course for teachers, I can \\
identify and discuss contrasting ways online education \\
can contribute to either narrowing or widening the \\
"Digital Divide."
\end{tabular}




\subsection{Concurrent Validity}

Concurrent validity aims to test whether an instrument correlates well with a measure that has previously been validated. The GSE survey (Schwarzer \& Jerusalem, 1995) was selected as the validated instrument for our study for two reasons. First, the GSE survey measured similar constructs (self-efficacy), and second, the GSE survey had been translated into 31 languages and validated by hundreds of studies (Schwarzer, n.d.).

As a measure of concurrent validity, correlation of individuals' total scores on 10 GSE and the 38 self-efficacy questions were calculated using Spearman's rho Correlation. The correlation coefficient $(0.725)$, showing in Table 7 , indicated a strong positive correlation between the two measures. and 25 might need revisions due to the excessive unexpected variability. These items simply performed in a manner counterintuitive to the measurement model. Rather than removing these items, it may be useful to evaluate them with content experts and make empirical judgments on them qualitatively rather than statistically.

Questions 5, 6, 7, 8, and 25 simply asked participants whether they could use built-in communication or wiki tools on Moodle. Because the survey was developed to measure teacher's self-efficacy in teaching online courses on Moodle, many questions specifically focused on LMS built-in functions and activities. The specificity might result in larger variances because teachers are already using alternative tools. For example, instead of using platform built-in communication tools, school districts might have their own

Table 7. Correlations of Individuals' total Scores on GSE and the OESES Questions

\begin{tabular}{|c|c|c|c|c|}
\hline & & & OESES_Items & $G S E \_I t e m s$ \\
\hline \multirow[t]{6}{*}{$\begin{array}{l}\text { Spearman's } \\
\text { rho }\end{array}$} & \multirow[t]{3}{*}{$\begin{array}{l}\text { OESES_- } \\
\text { Items }\end{array}$} & $\begin{array}{l}\text { Correlation } \\
\text { Coefficient }\end{array}$ & 1.000 & $.725 * *$ \\
\hline & & $\begin{array}{l}\text { Sig. } \\
\text { (2-tailed) }\end{array}$ & $\cdot$ & .000 \\
\hline & & $\mathrm{N}$ & 231 & 231 \\
\hline & \multirow[t]{3}{*}{$\begin{array}{l}\text { GSE_- } \\
\text { Items }\end{array}$} & $\begin{array}{l}\text { Correlation } \\
\text { Coefficient }\end{array}$ & $.725 * *$ & 1.000 \\
\hline & & $\begin{array}{l}\text { Sig. } \\
\text { (2-tailed) }\end{array}$ & .000 & - \\
\hline & & $\mathrm{N}$ & 231 & 231 \\
\hline
\end{tabular}

\section{Discussion}

Based on the results of the construct validity analysis, questions $5,6,7,8$, synchronous or asynchronous tools for instructional communications. Therefore, the researchers suggest revising some survey questions to be more general. 
For example, Question 6 can be revised to, "After the professional development training, I can send documents as email attachments." Poor course design or instruction could be another factor resulting in unidimensionality violation on these questions. However, more studies are required to confirm this inference.

The results of content validity show questions 13, 14, 40, 41, and 48 have lower scores of Content Validity Index (CVI) than the recommended threshold (0.8) (Davis, 1992). This means that these five questions cannot represent content within the target domain (effective online instruction) (Lawshe, 1975). After further examining CVI values and experts' comments, the researchers suggest deleting questions 40 and 41 because both questions ask about online teaching workload, rather than online teaching practice that could explain why their CVI values are zero. In addition, question 48 should also be deleted (Digital Divide, CVI=33.33\%), because it is not closely related to knowledge and skills for effective online teaching. Finally, the researchers suggest keeping both questions 13 and 14 because such knowledge is helpful for being a good instructor $(\mathrm{CVI}=66.67 \%)$. In addition, if the review panel increases to five experts, these two questions might be able to pass the recommended threshold.

\section{Summary and Conclusion}

The results of this study show that the OESES is in general a valid and reliable instrument. It can be used to assess the effectiveness of online PD programs and subsequent online instructors' knowledge and skills to teach online after receiving specific PD training for teaching online. This study not only informs the online learning community the availability of a valid and reliable assessment instrument (OESES), but also showcases how aspects of validity and reliability of an assessment instrument are determined.

There are different possible applications for the OESES including: (a) assessing the effectiveness of online PD programs, including workshops, courses, etc.; (b) assessing online instructor's subsequent performance of teaching online after completing a PD training; (c) screening and selecting the best applicants for online teaching positions; (d) supporting evidence-based online program evaluations; and (e) supporting effective "datadriven" decision-making for online program administrators.

The study has limitations. First, a selection bias in terms of the purposeful selection of survey participants may have contributed to the high coefficients of both the validity and reliability of the OESES survey. Therefore, more studies, with different approaches (such as Structural Equation Modeling) and participants, are necessary to further validate the instrument. 


\section{References}

Alagumalai, S., Curtis, D.D., \& Hungi, N. (2005). Applied Rasch measurement: A book of exemplars. Dordrecht, NL: Springer-Kluwer.

AERA, APA, \& NCME (1999). Standards for educational and psychological testing. Washington, DC: American Educational Research Association.

Ashton, P. T., \& Webb, R. B. (1986). Making a difference: Teachers' sense of efficacy and student achievement. New York: Longman.

Ashton, P. T., Webb, R. B., \& Doda, N. (1983). A study of teacher's sense of efficacy. Final report to the National Institute of Education. Gainesville, FL: Florida University.

Bandura, A. (1993). Perceived self-efficacy in cognitive development and functioning. Educational Psychologist, 28(2), 117-148.

Bandura, A. (1997). Self-efficacy: The exercise of control. New York, NY: Freeman.

Bond, T. G., \& Fox, C. M. (2007). Applying the Rasch model: Fundamental measurement in the human sciences. Mahwah, N.J: Lawrence Erlbaum Associates Publishers.

Bond, T. G., \& Fox, C. M. (2013). Applying the Rasch model: Fundamental measurement in the human sciences (2nd ed.). Hoboken, NJ: Taylor and Francis.

Brown, J. D. (1996). Testing in language programs. Upper Saddle River, NJ: Prentice Hall Regents.

Comer, C. M., Conaghan, P. G., \& Tennant, A. (2011). Internal construct validity of the Swiss spinal stenosis questionnaire: Rasch analysis of a disease-specific outcome measure for lumbar spinal stenosis. Spine, 36(23), 1969-1976.

Crocker, L., \& Algina, J. (1986) Introduction to classical and modern test theory, New
York: Holt, Rinehart, and Winston.

Cronbach, L. J. (1951). Coefficient alpha and the internal structure of tests. Psychometrika. 16, 297-334.

Davis, L. (1992). Instrument review: Getting the most from your panel of experts. Applied Nursing Research, 5, 194-197

Dawley, L., Rice, K., \& Hinck, G. (2010). Going virtual! 2010: The status of professional development and unique needs of $\mathrm{K}-12$ online teachers. White paper prepared for the North American Council for Online Learning. Washington, D.C. Retrieved from: http://www.inacol. org/research/docs/goingvirtual.pdf

Deubel, P. (2008). K-12 online teaching endorsements: Are they needed? T.H.E. Journal Smart Classroom. Retrieved from: http://www.thejournal.com/articles/21804

Faseyitan, S., Libii, J. N., \& Hirschbuhl, J. (1996). An inservice model for enhancing faculty computer self-efficacy. British Journal of Educational Technology, 27(3), 214-226.

Furr, R. M., \& Bacharach, V. R. (2007). Psychometrics: An introduction. Thousand Oaks, CA: Sage Publications.

Goddard, R. (2002). A theoretical and empirical analysis of the measurement of collective efficacy: The development of a short form. Educational and Psychological Measurement, 62(1), 97-110.

Goddard, R. D., \& Goddard, Y. L. (2001). A multilevel analysis of the relationship between teacher and collective efficacy in urban schools. Teaching and Teacher Education, 17, 807-818

Goddard, R. D., Hoy, W. K., \& Hoy, A. W. (2004). Collective efficacy beliefs: Theoretical developments, empirical evidence, and future directions. Educational Researcher, 33(3), 3-13.

Haney, J. J., Czerniak, C. M., \& Lumpe, A. T. (1996). Teacher beliefs and intentions regarding the implementation of science 
education reform strands. Journal of Research in Science Teaching, 33(9), 971993.

Hogan, T. P., Benjamin, A., \& Brezinski, K. L. (2000). Reliability methods: A note on the frequency of use of various types. Educational and Psychological Measurement, 60(4), 523-531.

Knight, A. M., Carrese, J. A., \& Wright, S. M. (2007). Qualitative assessment of the long $\square$ term impact of a faculty development programme in teaching skills. Medical Education, 41(6), 592-600.

Knoblauch, D., \& Hoy, A. W. (2008). "Maybe I can teach those kids." the influence of contextual factors on student teachers' efficacy beliefs. Teaching \& Teacher Education, 24(1), 166-179.

ISTE. (2008). NETS for Teachers. Retrieved from http://www.iste.org/standards/ standards-for-teachers/nets-forteachers-2008

iNACOL (2011). National standards for quality online teaching. Retrieved from http://www.inacol.org/ research/nationalstandards/iNACOL TeachingStandardsv2.pdf

Kyriakides, L., Kaloyirou, C., \& Lindsay, G. (2006). An analysis of the revised olweus bully/victim questionnaire using the Rasch measurement model. British Journal of Educational Psychology, 76(4), 781-801.

Lamb, R. L., Vallett, D., \& Annetta, L. (2014). Development of a short-form measure of science and technology self-efficacy using Rasch analysis. Journal of Science Education and Technology, 23(5), 641657.

Lawshe, C.H. (1975). A quantitative approach to content validity. Personnel Psychology, 28(4), 563-575.

Long, J. E. \& Moore, R. (2008). Motivating content: How interest and self-efficacy respond to subject matter taught in an alternative teacher education program. Catholic Education: A Journal of Inquiry and Practice, 11(4), 442-464.

Loucks-Horsley, S., Stiles, K., \& Hewson, P. (1996). Principles of effective professional development for Mathematics and Science education: A synthesis of standards. ERIC Clearinghouse. Retrieved from http:// wcer.wisc.edu/archive/nise/Publications/ Briefs/NISE_Brief_Vol_1_No_1.pdf

Lynn, M. (1986). Determination and quantification of content validity. Nursing Research, 35, 382-385.

Margolis, H., \& McCabe, P. P. (2006). Improving self-efficacy and motivation: What to do, what to say. Intervention in School and Clinic, 41(4), 218-227.

Martin, A. J., \& Marsh, H. W. (2006). Academic resilience and its psychological and educational correlates: A construct validity approach. Psychology in the Schools, 43(3), 267-281.

Messick, S. (1989). Validity. In R. L. Linn (Ed.), Educational measurement (3rd ed.) (pp. 13-104). New York, NY: American Council on Education, National Council on Measurement in Education.

Messick, S. (1995). Validity of psychological assessment: Validation of inferences from persons' responses and performances as scientific inquiry into score meaning. American Psychologist, 50(9), 741-749.

Milbrath, Y. C. L., \& Kinzie, M. (2000). Computer technology training for prospective teachers: Computer attitudes and perceived self-efficacy. Journal of Technology and Teacher Education, 8(4), 373-396.

Milner, H. (2002). A case study of an experienced teacher's self-efficacy and persistence through crisis situations: Theoretical and practical considerations. The High School Journal, 86(1), 28-35.

Overbaugh, R., \& Lu, R. (2008). The impact of a NCLB-EETT funded professional development program on teacher selfefficacy and resultant implementation. 
Journal of Research on Technology in Education, 41(1), 43-61.

Partnership for 21st Century Skills. (2011). Framework for $21 \mathrm{st}$ century learning. Retrieved from http://www.p21.org/ overview/skills-framework

Patrick, S., \& Dawley, L. (2009). Redefining teacher education: K-12 online-blended learning and virtual schools. The summit on redefining teacher education for digital age learners, Austin, TX: The University of Texas. Retrieved from http:// redefineteachered.org/sites/default/files/ SummitBriefPatrick.pdf

Rice, K. (2012). Making the move to K-12 online teaching: Research-based strategies and practices. Saddle River, NJ: Pearson Education.

Ross, J. A. (1998). The antecedents and consequences of teacher efficacy. In J. Brophy (Ed.), Research on Teaching. Vol. 7. (pp. 49-74). Greenwich, CT: JAI Press.

Ross, J., \& Bruce, C. (2007). Professional development effects on teacher efficacy: Results of a randomized field trial. The Journal of Educational Research, 101(1), $50-60$.

Royal, K. D., \& Tabor, A. J. (2008). Theories of student success: Evaluating the effectiveness of an intervention strategy. Retrieved from http://eric. ed.gov/?id=ED506514

Rubio, D. M., Berg-Weger, M., Tebb, S. S., Lee, E. S., \& Rauch, S. (2003). Objectifying content validity: conducting a content validity study in social work research. Social Work Research, 27(2), 94-104.

Runnels, J. (2012). Using the Rasch model to validate a multiple choice English achievement test. International Journal of Language Studies, 6(4), 141-153

Schwarzer, R. (n.d.). The general self-efficacy scale. Retrieved from http://userpage.fu- berlin.de/ health/engscal.htm

Schwarzer, R., \& Jerusalem, M. (1995). Generalized self-efficacy scale. In J. Weinman, S. Wright, \& M. Johnston (Eds.), Measures in Health Psychology: A user's portfolio. (pp. 35-37). Windsor, UK: Nfer-Nelson.

Shechtman, Z., Levy, M., \& Leichtentritt, J. (2005). Impact of life skills training on teachers' perceived environment and self-efficacy. The Journal of Education Research, 98(3), 144-154.

Siegle, D., \& McCoach, D. B. (2007). Increasing student Mathematics selfefficacy through teacher training. Journal of Advanced Academics, 18(2), 278-312.

Tschannen-Moran, M., Hoy, A. W., \& Hoy, W. K. (1998). Teacher efficacy: Its meaning and measure. Review of Educational Research, 68(2), 202-248.

Woolfolk Hoy, A., \& Davis, H. A. (2006). Teacher self-efficacy and its influence on the achievement of adolescents. In F. Pajares \& T. Urdan (Eds.), Self-efficacy of adolescents (pp. 117-137). Greenwich, Connecticut: Information Age Publishing.

Woolfolk Hoy, A., Davis, H., \& Pape, S. J. (2006). Teacher knowledge and beliefs. Handbook of Educational Psychology, 2, 715-738.

Woolfolk, A. E., Rosoff, B., \& Hoy, W. K. (1990). Teachers' sense of efficacy and their beliefs about managing students. Teaching and Teacher Education, 6(2), 137-148.

Wright, B. D., \& Masters, G. N. (1982). Rating scale analysis. Rasch measurement. Chicago, IL: MESA Press. 


\section{Contact the Author}

\section{Jui-Long Hung}

Department of Educational Technology, Boise

State University

1910 University Drive, Boise, Idaho 83725, USA

Tel:1-208-426-5542, Fax: 1-208-426-1451

Email:andyhung@boisestate.edu

\section{Dazhi Yang}

Department of Educational Technology, Boise State University

1910 University Drive, Boise, Idaho 83725, USA

Tel:1-208-426-3212, Fax: 1-208-426-1451, Email:dazhiyang@boisestate.edu

\section{Appendix: OESES Survey Questions}

\begin{tabular}{|c|c|c|}
\hline Number & Question Type & Question \\
\hline Q1-1 & Satisfaction & Pre-course notification and communication \\
\hline Q1-2 & Satisfaction & Relevance of course's goals to my own teaching practice \\
\hline Q1-3 & Satisfaction & Ability of presenters to tailor instructions to my needs. \\
\hline Q1-4 & Satisfaction & Workshop organization (clarity, agenda, logistics) \\
\hline Q1-5 & Satisfaction & Amount of time devoted to facilitation practice \\
\hline Q1-6 & Satisfaction & Knowledge of instructors \\
\hline Q1-7 & Satisfaction & Approachability of instructors \\
\hline Q1-8 & Satisfaction & Usefulness of the content \\
\hline Q2 & Satisfaction & $\begin{array}{l}\text { Please rate the contribution of OTA-121 to supporting you } \\
\text { to become an effective online educator. ( } 1=\text { low satisfaction } \\
\text { and } 4=\text { high satisfaction) }\end{array}$ \\
\hline Q3 & Satisfaction & $\begin{array}{l}\text { After completion of this course, I believe online educational } \\
\text { systems (Moodle and other LMS's, Wikis, Blogs and other } \\
\text { Web } 2.0 \text { educational environments) will be useful for } \\
\text { supporting my ongoing work as an educator. }\end{array}$ \\
\hline Q4 & Satisfaction & $\begin{array}{l}\text { Rate the online Teaching Associates course you participated } \\
\text { in regarding your overall satisfaction after completion. }\end{array}$ \\
\hline
\end{tabular}




\begin{tabular}{|c|c|c|}
\hline Q5 & OESES & $\begin{array}{l}\text { After completing OTA's course for teachers, I feel } \\
\text { comfortable using Moodle's discussion forums. }\end{array}$ \\
\hline Q6 & OESES & $\begin{array}{l}\text { After completing OTA's course for teachers, I can send } \\
\text { e-mail from inside a Moodle course }\end{array}$ \\
\hline Q7 & OESES & $\begin{array}{l}\text { After completing OTA's course for teachers, I can send } \\
\text { documents as e-mail attachments from inside a Moodle } \\
\text { course. }\end{array}$ \\
\hline Q8 & OESES & $\begin{array}{l}\text { After completing OTA's course for teachers, I feel } \\
\text { comfortable using Wimba's (or other) synchronous, online } \\
\text { classroom. }\end{array}$ \\
\hline Q9 & OESES & $\begin{array}{l}\text { After completing OTA's course for teachers, I can always } \\
\text { manage to solve difficult problems if I try hard enough. }\end{array}$ \\
\hline Q10 & OESES & $\begin{array}{l}\text { After completing OTA's course for teachers, if someone } \\
\text { opposes me, I can find the means and ways to get what I } \\
\text { want. }\end{array}$ \\
\hline Q11 & OESES & $\begin{array}{l}\text { After completing the OTA's course for teachers, it is easy } \\
\text { for me to stick to my aims and accomplish my goals. }\end{array}$ \\
\hline Q12 & OESES & $\begin{array}{l}\text { After completing OTA's course for teachers, I feel } \\
\text { comfortable discussing ways online teaching and learning } \\
\text { compares with teaching and learning in traditional } \\
\text { educational environments. }\end{array}$ \\
\hline Q13 & OESES & $\begin{array}{l}\text { After completing OTA's course for teachers, I feel } \\
\text { comfortable discussing the history of contemporary online } \\
\text { education. }\end{array}$ \\
\hline Q14 & OESES & $\begin{array}{l}\text { After completing OTA's course for teachers, I am able to } \\
\text { knowledgeably discuss national and state online teaching } \\
\text { standards and the credentialing of online teachers. }\end{array}$ \\
\hline Q15 & OESES & $\begin{array}{l}\text { After completing OTA's course for teachers, I can } \\
\text { compare and discuss similarities and differences between } \\
\text { synchronous and asynchronous online instructional } \\
\text { environments (i.e. the Wimba Classroom and Moodle } \\
\text { Forum, respectively). }\end{array}$ \\
\hline Q16 & OESES & $\begin{array}{l}\text { After completing OTA's course for teachers, I am confident } \\
\text { that I could deal efficiently with unexpected events. }\end{array}$ \\
\hline Q17 & OESES & $\begin{array}{l}\text { After completing OTA's course for teachers, thanks to } \\
\text { my resourcefulness, I know how to handle unforeseen } \\
\text { situations. }\end{array}$ \\
\hline Q18 & OESES & $\begin{array}{l}\text { After completing OTA's course for teachers, I can solve } \\
\text { most problems if I invest the necessary effort. }\end{array}$ \\
\hline
\end{tabular}


The Validation of an Instrument for Evaluating the Effectiveness of Professional

Development Program on Teaching Online

\begin{tabular}{|c|c|c|}
\hline Q19 & OESES & $\begin{array}{l}\text { After completing OTA's course for teachers, I can remain } \\
\text { calm when facing difficulties because I can rely on my } \\
\text { coping abilities. }\end{array}$ \\
\hline Q20 & OESES & $\begin{array}{l}\text { After completing OTA's course for teachers, when I am } \\
\text { confronted with a problem, I can usually find several } \\
\text { solutions. }\end{array}$ \\
\hline Q21 & OESES & $\begin{array}{l}\text { After completing the OTA's course for teachers, if I am in } \\
\text { trouble, I can usually think of a solution. }\end{array}$ \\
\hline Q22 & OESES & $\begin{array}{l}\text { After completing the OTA's course for teachers, I can } \\
\text { usually handle whatever comes my way. }\end{array}$ \\
\hline Q23 & OESES & $\begin{array}{l}\text { After completing OTA's course for teachers, I can find } \\
\text { suitable, high quality, discipline-based instructional content } \\
\text { by searching on the worldwide web. }\end{array}$ \\
\hline Q24 & OESES & $\begin{array}{l}\text { After completing OTA's course for teachers, I am able to } \\
\text { support my students to be more selective about selecting } \\
\text { and screening internet resources for use as sources for } \\
\text { research projects for writing assignments required in my } \\
\text { class. }\end{array}$ \\
\hline Q25 & OESES & $\begin{array}{l}\text { After completing OTA's course for teachers, I would } \\
\text { consider using a Wiki for supporting a discipline-based } \\
\text { online educational activity with one or more of my classes. }\end{array}$ \\
\hline Q26 & OESES & $\begin{array}{l}\text { After completing OTA's course for teachers, I feel } \\
\text { comfortable using web-based resources for supporting my } \\
\text { discipline-based teaching. }\end{array}$ \\
\hline Q27 & OESES & $\begin{array}{l}\text { After completing OTA's course for teachers, I am able to } \\
\text { explain and discuss why prompt instructor feedback is } \\
\text { important for effective teaching and online learning. }\end{array}$ \\
\hline Q28 & OESES & $\begin{array}{l}\text { After completing OTA's course for teachers, I can discuss } \\
\text { facilitation techniques that support student interaction in } \\
\text { asynchronous discussion forums, like Moodle's discussion } \\
\text { forums. }\end{array}$ \\
\hline Q29 & OESES & $\begin{array}{l}\text { After completing OTA's course for teachers, I can discuss } \\
\text { facilitation strategies that support student interaction } \\
\text { in synchronous online discussions, like in the Wimba } \\
\text { Classroom and similar real-time forums. }\end{array}$ \\
\hline Q30 & OESES & $\begin{array}{l}\text { After completing OTA's course for teachers, I feel } \\
\text { comfortable facilitating assignments online requiring } \\
\text { students to submit posting and responses in Moodle } \\
\text { discussion forms. }\end{array}$ \\
\hline Q31 & OESES & $\begin{array}{l}\text { After completing OTA's course for teachers, I feel } \\
\text { comfortable facilitating synchronous real-time discussions } \\
\text { in online educational environments like the Wimba } \\
\text { Classroom. }\end{array}$ \\
\hline
\end{tabular}




\begin{tabular}{|c|c|c|}
\hline Q32 & OESES & $\begin{array}{l}\text { After completing OTA's course for teachers, I can defend } \\
\text { and discuss the following statement: "Instructional } \\
\text { collaboration and classes organized as learning } \\
\text { communities contribute to improved teaching and learning } \\
\text { in both traditional and online learning environments." }\end{array}$ \\
\hline Q33 & OESES & $\begin{array}{l}\text { After completing OTA's course for teachers, I can describe } \\
\text { and discuss traits or characteristics shared by many } \\
\text { successful online learners. }\end{array}$ \\
\hline Q34 & OESES & $\begin{array}{l}\text { After completing OTA's course for teachers, I can describe } \\
\text { and discuss accessibility issues (ADA Sections 504/508) as } \\
\text { they relate to online educational practice. }\end{array}$ \\
\hline Q35 & OESES & $\begin{array}{l}\text { After completing OTA's course for teachers, I feel } \\
\text { comfortable including "exceptional" students in online or } \\
\text { blended learning activities in my classes. }\end{array}$ \\
\hline Q36 & OESES & $\begin{array}{l}\text { After completing OTA's course for teachers, I am prepared } \\
\text { to personally assure all the instructional materials } \\
\text { and activities used in my classes comply with Federal } \\
\text { regulations requiring all online educational environments to } \\
\text { be full "accessible" by students with disabilities (i.e. ADA } \\
\text { Sections 504/508). }\end{array}$ \\
\hline Q37 & OESES & $\begin{array}{l}\text { After completing OTA's course for teachers, I can describe } \\
\text { and discuss assessment strategies suitable for assuring } \\
\text { academic accountability in online learning environments. }\end{array}$ \\
\hline Q38 & OESES & $\begin{array}{l}\text { After completing OTA's course for teachers, I can identify } \\
\text { and plan for typical instructional problems affecting online } \\
\text { and blended learning environments. }\end{array}$ \\
\hline Q39 & OESES & $\begin{array}{l}\text { After completing OTA's course for teachers, I can describe } \\
\text { and discuss facilitation strategies and techniques useful for } \\
\text { maintaining productive and efficient online and blended } \\
\text { learning environments. }\end{array}$ \\
\hline Q40 & OESES & $\begin{array}{l}\text { After completing OTA's course for teachers, I can describe } \\
\text { and discuss common factors contributing to heavy demands } \\
\text { on teachers' time ( } 24 / 7) \text { from fully online and blended } \\
\text { teaching assignments. }\end{array}$ \\
\hline Q41 & OESES & $\begin{array}{l}\text { After completing OTA's course for teachers, I am confident } \\
\text { I can successfully manage workload demands from an } \\
\text { online or blended teaching assignment. }\end{array}$ \\
\hline Q42 & OESES & $\begin{array}{l}\text { After completing OTA's course for teachers, I can } \\
\text { describe and discuss ways online instruction can } \\
\text { effectively contribute to enriching and expanding learning } \\
\text { opportunities for students in traditional classroom. }\end{array}$ \\
\hline Q43 & OESES & $\begin{array}{l}\text { After completing OTA's course for teachers, I can explain } \\
\text { to other online educators ways online instruction can } \\
\text { be used to support students' academic performance in } \\
\text { traditional classroom setting. }\end{array}$ \\
\hline
\end{tabular}




\begin{tabular}{|l|l|l|}
\hline Q44 & OESES & $\begin{array}{l}\text { After completing OTA's course for teachers, I feel prepared } \\
\text { to begin integrating online learning activities for supporting } \\
\text { and enriching instruction in my traditional, face-to-face } \\
\text { classes. }\end{array}$ \\
\hline Q45 & OESES & $\begin{array}{l}\text { After completing OTA's course for teachers, I can identify } \\
\text { and discuss a variety of online "threats" that potentially put } \\
\text { my students "at risk." }\end{array}$ \\
\hline Q46 & OESES & $\begin{array}{l}\text { After completing OTA's course for teachers, I understand } \\
\text { and can discuss the issues covered under our district's } \\
\text { "acceptable use policy" or AUP. }\end{array}$ \\
\hline Q47 & OESES & $\begin{array}{l}\text { After completing OTA's course for teachers, I am able } \\
\text { to identify and discuss a variety of socio-cultural issues } \\
\text { relevant to participation in online education. }\end{array}$ \\
\hline Q49 & OESES & $\begin{array}{l}\text { After completing OTA's course for teachers, I can identify } \\
\text { and discuss contrasting ways online education can } \\
\text { contribute to either narrowing or widening the "Digital } \\
\text { Divide." }\end{array}$ \\
\hline O50 & $\begin{array}{l}\text { After completing OTA's course for teachers, I can identify } \\
\text { and discuss issues related to digital copyright, licensing and } \\
\text { intellectual property. }\end{array}$ \\
\hline OES1 & $\begin{array}{l}\text { After completing OTA's course for teachers, I am prepared } \\
\text { to inform my students about digital copyright and } \\
\text { intellectual property laws and will require their full, lawful } \\
\text { compliance with these statutes while they participate in my } \\
\text { classes. }\end{array}$ \\
\hline Q52 & $\begin{array}{l}\text { After completing OTA's course for teachers, I can identify } \\
\text { and discuss cultural and linquistic diversity issues related to } \\
\text { online education. }\end{array}$ \\
\hline OESES & $\begin{array}{l}\text { After completing OTA's course for teachers, I feel prepared } \\
\text { to implement online educational activities that will address } \\
\text { and support cultural diversity. }\end{array}$ \\
\hline
\end{tabular}

